\title{
Public-private partnership model selection for dry port development: an application to Vietnam
}

\author{
Lam Canh Nguyen* \\ Faculty of Applied Economics, \\ University of Antwerp, \\ Kipdorp 59, 2000 Antwerp, Belgium \\ Email: nguyencanhlam.vimaru@gmail.com \\ *Corresponding author
}

\section{Theo Notteboom}

China Institute of FTZ Supply Chain,

Shanghai Maritime University,

1336 Dongming Road, Pudong New Area, Shanghai, China

and

Maritime Institute,

Faculty of Law,

Ghent University, Belgium

and

Faculty of Applied Economics,

University of Antwerp, Belgium

and

Antwerp Maritime Academy, Belgium

Email: theo.notteboom@gmail.com

\begin{abstract}
This paper aims at building a conceptual framework to support decision makers in selecting the best public-private partnership (PPP) model for dry port development. We focus on a classification of four PPP categories: contracting out, inland terminal concession, field concession and privatised ownership. The framework is based on a multi-criteria analysis with benefit-risk approach. Using multi-stakeholder theory, we break down the benefit hierarchy in benefits to public and community actors, benefits to private investors and financiers and benefits to dry port users. We also present a typology on the risk management ability of each model at the macro, meso and micro levels. The proposed framework is applied to the Vinh Phuc ICD project in Vietnam. In the case study, the four PPP models are assessed on their suitability and risk profile to find the preferred PPP model. The robustness of the outcomes is further tested using a sensitivity analysis.
\end{abstract}

Keywords: public-private partnership; PPP; dry port; multi-criteria; Vietnam; stakeholders; benefit-risk analysis.

Reference to this paper should be made as follows: Nguyen, L.C. and Notteboom, T. (2017) 'Public-private partnership model selection for dry port development: an application to Vietnam', World Review of Intermodal Transportation Research, Vol. 6, No. 3, pp.229-250. 
Biographical notes: Lam Canh Nguyen is a $\mathrm{PhD}$ candidate at the University of Antwerp in Belgium. He is also a Lecturer of Vietnam Maritime University in Hai Phong, Vietnam. His research interests include transport and maritime management, dry ports and hinterland connection. He has published articles in the Asian Journal of Shipping and Logistics and Journal of International Logistics and Trade.

Theo Notteboom published widely on port and maritime economics and management. He is a Research Professor at the China Institute of FTZ Supply Chain at Shanghai Maritime University. He holds a Chair Professorship 'Port of Ghent' at Ghent University in Belgium. He also is a part-time Professor at University of Antwerp and the Antwerp Maritime Academy in Belgium. $\mathrm{He}$ previously was a Professor at Dalian Maritime University in China. He is immediate past President and council member of International Association of Maritime Economists (IAME). He is an editor or a member of the editorial boards of a large number of academic journals in the field. $\mathrm{He}$ is the co-Director of Porteconomics.eu, a knowledge dissemination platform on port studies.

\section{Introduction}

Increasing global trade, containerisation and the massification of sea shipments have put huge pressures on port-hinterland distribution. Off-dock terminals arose to improve the connectivity between seaports and inland destinations. There is no global consensus on the definition of such inland terminals. Different terminologies have been used in different situations as synthesised in the work of Notteboom and Rodrigue (2009), Cullinane et al. (2012) and Notteboom et al. (2017). Although the term inland clearance depot (ICD) is widely used in developing countries like India, Nigeria and Vietnam, such terminals have gone beyond the mere functionalities of multimodal service, container depot and custom clearance. In the USA, the term inland port is more commonly used for inland locations. Other related concepts and terms being used include interporti in Italy, plateformes logistiques in France, GVZ in Germany, freight villages, logistics parks as well as dry ports. We use the term dry port in this paper. The term dry port evolved from an intermodal terminal used in bill of ladings issued by shipping lines (UNCTAD, 1982) to a broader use as defined by Roso et al. (2009). A dry port is an intermodal terminal with direct links to seaports using barge or rails shuttles and providing or co-located with a wide range of logistics services.

In developed economies which reached the phase of regionalisation (Notteboom and Rodrigue, 2005), dry ports are typically developed by maritime-based players, such as port operators, as an extension of seaport activity or to improve hinterland access. Dry ports in developing countries are mostly land-driven, meaning that they are purposely developed by land actors, such as local authority or rail companies, to serve the local production bases. Moreover, they are situated in the proximity, or even inside the industrial zones to serve the many small local shippers, or in the middle of the chain for transloading between two transport networks. The connectivity to seaports is loose because of their over-reliance on road connections and a lack of trained/experience human resource and technology (Nguyen and Notteboom, 2016a). 
The government often takes the responsibility of dry port planning and facilitates dry port development in such undeveloped systems. In many developing countries, state-owned enterprises play a key role in financing and operating most major transport infrastructure projects. However, as the container demand is growing, the public sector is short of funds for such investment, including dry port development. Another problem relates to the lack of expertise and experience, leading to inferior operations and maintenance. Public-private partnership (PPP) is considered as a solution to mobilise funds from the private sector and to improve public service efficiency. In short, PPP is a contract between the government and private sector in providing a specific public service. Such partnership requires the risks, responsibilities and return to be shared between the public and private sector.

This paper aims at developing a tool to assist stakeholders in selecting the best PPP model for specific dry port projects. The proposed PPP scheme supports two goals:

1 to find a best fit for the objectives of relevant stakeholders, including public actors, private consortium and users

2 to find a PPP model that best manages risk allocation of the PPP model and the ability of the responsible party.

A multi-criteria and multi- stakeholder approach is followed in this research.

The paper is structured as follows. We first review the literature on PPP in the transport sector which serves as input for the identification of relevant PPP and governance arrangements for a dry port setting. Then, the paper presents a conceptual framework for benchmarking PPP models in dry port development. Before turning to the conclusions, the proposed model is applied to a new dry port project in Vinh Phuc Province in Vietnam. This project entails a central ICD for serving the large market areas of Vinh Phuc, Tuyen Quang, Thai Nguyen, Ha Giang and Phu Tho.

\section{PPPs in dry ports: types, characteristics and governance issues}

\subsection{The notion of PPP in a dry port context}

There is no common concept of PPP worldwide (PPPIRC, 2014). Each country has its own definition and application framework for such partnerships. As defined by Public-Private-Partnership in Infrastructure Resource Center (PPPIRC) of the World Bank Group, a PPP should have the following characteristics:

1 long-term agreement, where

2 public and private act together in sharing risk and responsibility

3 in the provision of public service and delivery of public infrastructure.

Traditional public procurement and full privatisation are not considered as PPP. The potential advantages of PPP include the acceleration of public infrastructure provision; faster implementation and lifecycle cost reduction thanks to the private involvement in construction, operation and maintenance; better risk allocation where the risk is transferred to the party best able to manage it; better performance and higher efficient use 
of resource by the private operator; the public management will be improved by focusing on the roles of regulating, planning and monitoring (European Commission, 2003).

Table 1 Main types of PPPs and their characteristics

\begin{tabular}{|c|c|c|c|c|c|c|c|c|}
\hline Index & $\begin{array}{l}\text { Types of } \\
\text { PPPs }\end{array}$ & Acronym & $\begin{array}{c}\text { Mode of } \\
\text { entry }\end{array}$ & $\begin{array}{c}\text { Operation } \\
\text { and } \\
\text { maintenance }\end{array}$ & Investment & $\begin{array}{c}\text { Ultimate } \\
\text { ownership }\end{array}$ & Market risk & $\begin{array}{c}\text { Duration } \\
\text { (years) }\end{array}$ \\
\hline 1 & $\begin{array}{l}\text { Management } \\
\text { contract }\end{array}$ & & Contract & Private & Public & Public & Public & $3-5$ \\
\hline 2 & Leasing & & Contract & Private & Public & Public & Semi-private & $8-15$ \\
\hline 3 & $\begin{array}{l}\text { Rehabilitate, } \\
\text { operate and } \\
\text { transfer }\end{array}$ & ROT & Concession & Private & Private & Public & Semi-private & $20-30$ \\
\hline 4 & $\begin{array}{l}\text { Rehabilitate, } \\
\text { lease/rent } \\
\text { and transfer }\end{array}$ & RLRT & Concession & Private & Private & Public & More-private & $20-30$ \\
\hline 5 & Merchant & & Greenfield & Private & Private & Public & More-private & $20-30$ \\
\hline 6 & $\begin{array}{l}\text { Build, } \\
\text { rehabilitate, } \\
\text { operate and } \\
\text { transfer }\end{array}$ & BROT & Concession & Private & Private & Public & Private & $20-30$ \\
\hline 7 & $\begin{array}{l}\text { Build, own } \\
\text { and transfer }\end{array}$ & BOT & Greenfield & Private & Private & Semi-private & Private & $20-30$ \\
\hline 8 & $\begin{array}{l}\text { Build, own, } \\
\text { operate and } \\
\text { transfer }\end{array}$ & BOOT & Greenfield & Private & Private & Semi-private & Private & $30+$ \\
\hline 9 & $\begin{array}{l}\text { Build, lease } \\
\text { and own }\end{array}$ & BLO & Greenfield & Private & Private & Private & Private & $30+$ \\
\hline 10 & $\begin{array}{l}\text { Build, own } \\
\text { and operate }\end{array}$ & $\mathrm{BOO}$ & Greenfield & Private & Private & Private & Private & $30+$ \\
\hline 11 & $\begin{array}{l}\text { Partial } \\
\text { privatisation }\end{array}$ & & Divesture & Private & Private & Private & Private & $30+$ \\
\hline 12 & $\begin{array}{l}\text { Full } \\
\text { privatisation }\end{array}$ & & Divesture & Private & Private & Private & Private & Indefinite \\
\hline
\end{tabular}

Source: Hammami et al. (2006)

There are a variety of PPP models with different levels of private involvement in terms of investment, ownership and risk transferred as shown in Table 1. Each type of PPP model has its own advantages and disadvantages, and a different effectiveness and suitability in different sectoral and project contexts (European Commission, 2003). In the transport sector, many studies have focused on the application of PPP schemes in road, rail and seaport projects (The World Bank, 2003; PPIAF, 2009; Turpin, 2013; Farrell and Vanelslander, 2015). However, there is little literature on PPP models in a dry port context. Beresford et al. (2012) suggest that dry ports might follow the management framework which has been applied to seaports, including service port, tool port and landlord port. Nevertheless, they did not go further to explain which PPP options could be applied within such management models. When applying PPP models to dry ports, one has to identify the characteristics of dry port projects, such as: 
1 high investment in both construction and operation and maintenance

2 the private operator generates the revenues directly from users (mostly local exporters, shippers, forwarders, seaport operators), not from the government repayment or contributions

3 heavy reliance on the strong connectivity in terms of transport infrastructure, the range of transport and shuttle services to seaports (by railway, inland water way or road)

4 connections to the industrial zones and local markets.

\subsection{Four main PPP models relevant to dry port development}

In this paper, we focus on four main PPP models in dry port development. The selection of the four models is based on the characteristics of dry ports in developing countries, the PPP classifications as presented in European Commission (2003), The World Bank (2015), Shukla et al. (2014) and Yescombe (2011), experience with PPP in seaports and airports (Aerts et al., 2014; Farrell, 2011; Farrell and Vanelslander, 2015; Turpin, 2013), case studies of PPP in dry ports such as Thailand (APEC, 2015), Republic of Korea (Hanaoka and Regmi, 2011) and India (Haralambides and Gujar, 2011) and interviews with experts in dry port PPP conducted in Belgium and Vietnam in early 2016. The differences between the PPP models are mainly found at the level of the involvement of the private sector in investment and ownership. The sub division is made according to the level of risk transfer from public entities to private players.

Table 2 Main PPP models in dry port development considered in this study

\begin{tabular}{|c|c|c|c|}
\hline & Private investment & Private ownership & Sub-division \\
\hline $\begin{array}{l}\text { Contracting } \\
\text { out }\end{array}$ & $\begin{array}{l}\text { No or minor } \\
\text { private investment }\end{array}$ & $\begin{array}{l}\text { No private } \\
\text { ownership } \\
\text { involved }\end{array}$ & $\begin{array}{l}\text { - Management contract, O\&M, } \\
\text { turnkey, DB, DBO... } \\
\text { - Leasing contract }\end{array}$ \\
\hline $\begin{array}{l}\text { Inland } \\
\text { terminal } \\
\text { concession }\end{array}$ & $\begin{array}{l}\text { Significant private } \\
\text { investment in } \\
\text { superstructures }\end{array}$ & $\begin{array}{l}\text { No private } \\
\text { ownership }\end{array}$ & \\
\hline $\begin{array}{l}\text { Field } \\
\text { concession }\end{array}$ & $\begin{array}{l}\text { The private bears } \\
\text { most of investment } \\
\text { (infra and } \\
\text { superstructures) }\end{array}$ & $\begin{array}{c}\text { No private } \\
\text { ownership after the } \\
\text { contract } \\
\text { termination }\end{array}$ & $\begin{array}{ll}\text { - } & \text { BOT, BOOT } \\
\text { - } & \text { BTO } \\
\text { - } & \text { BROT }\end{array}$ \\
\hline $\begin{array}{l}\text { Privatised } \\
\text { ownership }\end{array}$ & $\begin{array}{l}\text { Part or whole } \\
\text { investment }\end{array}$ & $\begin{array}{l}\text { Part or whole } \\
\text { ownership is } \\
\text { privatised }\end{array}$ & $\begin{array}{ll}\text { - } & \mathrm{BOO} \\
\text { - } & \text { Divestiture }\end{array}$ \\
\hline
\end{tabular}

Source: Own compilation based on various sources

Contracting out means that the government bears the whole investment and maintains the ownership of the project. The government outsources one or a bundle of tasks to the private contractors in order to utilise the expertise of the private sector, such as designing, construction, operation and maintenance. The risks of cost overrun, low quality, late delivery of such tasks are transferred to the private sector. Example of this is design build (DB), design build operation maintenance (DBOM). Under a management contract, the 
private entity is hired by the public authority to manage the terminal operations. In a leasing contract, all public infrastructure and superstructures are leased to a private entity. Such private actor will manage the terminal, collect the user fee and pay the leasing fee to the public actor without making significant investments. The advantage of the contracting out model is that the government maintains most control over the facility as in the traditional publicly-owned projects. The government will utilise the expertise of the private sector in the task that they contract out. The biggest drawback is that the government has to fund the project by themselves and assumes most of the risks. The debt of capital investment will be accountable in the public books, and the government has to bear any losses linked to ICD operations while also keeping any profits made.

When using a terminal concession, the public sector has the ownership of the dry port. In this model, the public sector invests in the basic infrastructure and transport connections to the dry port. The public sector owns the dry port-related land and is responsible for dry port planning. The private actor bears significant investments in terminal superstructure, handling equipment and warehouses and might also take part in infrastructure investments such as additional railways to connect to the national railway system. The agreement is often awarded to the private sector in the form of concession, or infrastructure leasing where the operation is given to the private actor for a specific period of time (10-30 years). The private party, or the concessionaire in this case, pays concession fees to the public party and transfers all facilities to the public sector at the end of the concession term. An example is the Lat Krabang Inland Container Depot (APEC, 2015). This model shares similarities with the landlord model in the port sector. Under a terminal concession, the government retains the whole ownership of the dry port and acts as a landlord. Therefore, the government keeps control over the design, planning, and operation of the facility. The commercial risks, operations and maintenance tasks are transferred to the private actor. The public party sets the concession duration, the minimum throughput and key performance indicators. The private sector also feels more attracted by this model since their investment will concentrate in the capital goods and assets that generate revenues, such as handling equipment, storage facilities, etc. In the case the operator does not perform well, or the market fails, the contract might end up with a lose-lose situation instead of a win-win. The win-lose scenario is possible if the operator benefits from the monopolistic position and high tariffs without making efforts to improve the terminal throughput.

In a field concession, a private actor assumes the entire project investment in exchange of the right to operate the dry port. The ownership still belongs to the public sector at the end of the contract. The private party receives a concession from the public authority to finance, design, construct and operate the terminal. The private player collects the user fees to recover its investments and to generate revenues. The public sector guarantees the transport infrastructure connections to the dry port such as railways, inland waterways and seaport planning to assure the feasibility of the project. The ownership of the dry port will be transferred to the public player after construction or at the end of the contract. An example can be found in the case of the dry port project in Dosso and Niamey, Nigeria where Bolloré Africa Logistics won a 20-year concession with the committed investment of $\$ 78$ million to build, develop and operate the terminal facility (IFC, 2015). This category includes build-operate-transfer (BOT), build-transfer-operate (BTO), build-own-operate-transfer (BOOT) and other variations, which apply to greenfield projects and BROT (Build, rehabilitate, operate, transfer) for brownfield projects. The field concession relieves the government from the investment 
burden, but creates more complexity in terms of project control. The public actor loses the control over what should be built, how long it will take, and how it will perform. The worst case that might happen is that the private party constructs the facility too slow and even goes bankrupt, and the social benefits are threatened.

In the privatised ownership model, the private player is a full or partial facility owner. There are two main PPP schemes belonging to this category, include build-own-operate (BOO) and divestiture. The former is similar to the field concession model, but the ownership stays with the private actor after the end of the contract. The latter implies that the public partly or fully sells the existing terminal to the private sector. Examples of BOO could be found in several ICDs in Korean, e.g., Yangsan, Sejong, Chilgok, Jangseong. The privatised ownership category does not require public funding while most of the risks are transferred to the private sector. However, government control is limited to the role of regulator. This could be considered as the intermediate step towards full terminal privatisation.

The above four groups cover the most important PPP investment and funding options for dry port development.

\subsection{Key governance issues of PPPs in dry port development}

The governance theory can be applied to PPPs in order to achieve better outcomes (Chhotray and Stoker, 2008). We apply the typology of governance relationships at intermodal terminals and logistics platforms developed by Monios (2015) in view of discussing the governance relationships affecting the PPP solutions mentioned earlier. The typology of Monios (2015) includes four perspectives:

1 the development process of the properties

2 the relation between owner and operator

3 the relation between terminal operator and logistics platform

4 the relations between terminal and seaport.

In terms of the development process, our research focuses on dry port projects in developing countries, where the government takes the role of developer. In contrast to a real estate developer, whose interest is profit, public developers typically aim at facilitating the regional economy and modal shift (from road to rail or inland waterway) to provide social benefits. The government will first launch a feasibility research to start the dry port project. It has the option to invest and build the terminals by itself, as in the traditional public service, or hire a private company to construct, and then lease the property. The government might lease the whole greenfield for the private company, or build the infrastructure and lease the property through concessions. The public developers then decide which type of PPP model is suitable for the project, in terms of achieving their objectives of protecting social benefits, but also taking into account the financial viability of the project and other stakeholders' concerns. Next, the government will start searching for private partners. At this stage, the private parties are welcomed to investigate the project with the public support to decide if they want to join the bidding. The private entity entering the partnership might be a sole company, or a consortium of companies. The potential private partners include domestic and international real estate 
developers, transport operators, 3PLs, seaport players, shipping lines, logistics platform, construction companies, etc.

The relation between owner and operator will follow the PPP contract. Under Contracting out, the government might operate the facility themselves or through an arm's length company, or hire a private operator. In other cases, the private partner will operate a company under the PPP contract by themselves or subcontract to a third party operator.

The relation between the terminal and logistics platform is also worth analysing. In developing countries, logistics centres and intermodal terminals are often small and developed separately as they follow the scattered export-based areas and underdeveloped national transport system. However, a close relation with the logistics platform secures traffic for the terminal and in turn, using the inland terminal will facilitate the logistics services of the platforms. Therefore, the government might plan to co-locate or integrate those entities in a new project in the proximity of local industrial zones. Alternatively, existing logistics platforms might be interested in holding shares in a consortium which enters in PPP contracts for the new terminals.

Finally, in terms of the relations between terminals and seaports, sea actors such as port authorities, shipping lines, terminal operators might be interested in investing in inland terminals to improve their hinterland accessibility and secure traffic. Another way for collaborating is through joint service operation with the dry port. In case no close relationships exist, dry port players are free to choose which seaports to use for their cargo. Transport companies like rail service providers or barge companies also benefit from the close relationship with the dry port to improve their traffic flows. Therefore, it is suggested that the public developer should promote such relations in order to achieve a better dry port governance.

\section{Conceptual framework on the selection of a PPP model in dry port development}

\subsection{Methodological considerations}

Finding the appropriate PPP model is an imperative task during dry port development. This is the first task of the government before developing the full project and before calling for private participation. By choosing the proper model, the government needs to be sure that its objectives are met, uncertainty is minimised while the model still remains financially attractive to the private sector.

This is a huge challenge that hinders the implementation of PPP in dry ports in developing countries. These countries often lack experience in working with the private sector in terminal development. Legal and institutional frameworks available are often weak and there is a general lack of data records. In countries like Vietnam, the PPP concept is widely applied in utility, road and highway projects. However, the application in a terminal context is at its infancy stage. Most of the seaports were developed following traditional public procurement. The Lach Huyen seaport is the first project being developed in PPP under the landlord model. 
We argue that the selection of the most appropriate PPP model in dry port development should benefit from a methodological framework based on:

1 a multi-stakeholder approach in which the objectives of different stakeholders are considered

2 a multi-criteria approach with the inclusion of both quantitative and qualitative factors in a hierarchical analysis

3 a benefit-risk approach

4 the full consideration of the specific characteristics of dry ports.

First, a multi-stakeholder perspective is an essential requirement due to involvement of a wide range of stakeholders in dry port development. The stakeholder theory (Freeman, 2010) emphasises the importance of approaching different stakeholders based on their urgency, legitimacy and power in creating value for shareholders. The stakeholders in a PPP project are not limited to the public and private party in the contract, but also include the community, whose interest is represented by the government; the terminal users such as shippers, forwarders and transport companies; the seaport actors who have connections with the new dry port; and the financier of the project. Each stakeholder has its own interest and could influence the model selection directly or indirectly. The government as the project planner looks for the model that solves the problem of budget restrictions and protects the social interest in fulfilling the responsibility of providing public infrastructure. The private actor and their financier simply care about the financial viability of the project. The direct users and other players in the seaport and the hinterland share the same interest of logistics desirability of the project. They bear the cost of tax and user charges and would influence both public and private parties in the sense that their satisfaction will secure the income for the investors and improve regional trade.

Second, each stakeholder has different factors influencing their preference for specific PPP models, which might be quantitative and qualitative, economic or a more social nature. Multi-criteria analysis with the application of analytical hierarchy process (AHP) and analytical network process (ANP) (Saaty, 2008) could help to include all such factors with different units in one framework by using judgement of one alternative over another, or using qualitative approaches such as the Likert scale. Such approach can give a reasonable solution for a strategic question of the selection of a PPP model before a more detailed public call for private participation is developed.

Third, we argue that a benefit-risk approach is appropriate as PPP arrangements are different from other procurements by bundling rewards, risks and responsibilities of all stakeholders together (Becker and Patterson, 2005; Checherita and Gifford, 2007). The benefits relate to the achievements of each stakeholder in case the project is successful. It includes factors influencing each party's preference over the PPP successful outcomes. Different PPP arrangements would benefit each party in different ways depending on their objectives. The government and community aim at improving regional logistics and protecting social interests without worsening the public budget burden. Private investors and financiers are interested in return on investment. Dry port users like local shippers or transport companies mainly care about service quality and cost. Additionally, PPP arrangements are subjected to risks due to the long-term nature of the agreement, huge investments, high irreversibility, and high complexity of dry port projects (Checherita 
and Gifford, 2007). Different PPP arrangements lead to a variation in risk allocation in the project. In contrast to benefits, where each party has its own interest, risk management results from a responsibility of all stakeholders which can not be separated. According to PPIAF (2012), the partnership between public and private actors will allow for a better risk allocation and management than developed by pure public or private actors as each party absorbs different kinds of risks. Van Ham and Koppenjan (2001) argued that such partnership could only be realised when parties could understand mutual risks and work together to assign how such risks should be managed. Therefore, although the objectives of each stakeholder are different, risk management should be approached in an integrated way.

Lastly, the characteristics of dry port development should be considered when developing the criteria in the analysis. This includes a legal and institutional framework for dry port development in the given context; the nature of the transport market and the connectivity to seaports; the competition with other transport modes and other large and small ICDs, to name but a few.

Figure 1 Framework for PPP model selection (see online version for colours)

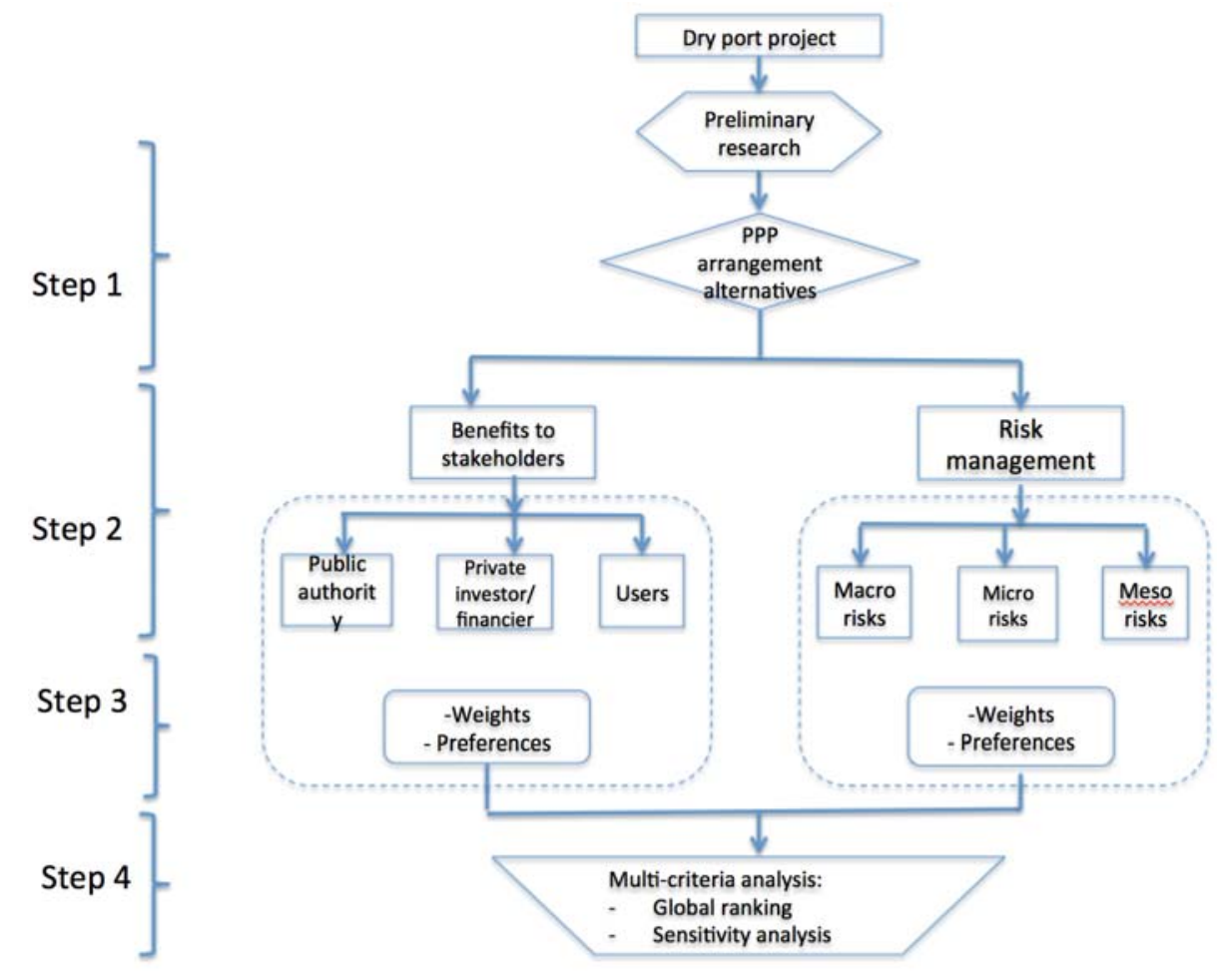

Source: Authors 


\subsection{Conceptual framework for PPP model selection in dry port development}

Based on the above considerations, we present a framework on PPP model selection for dry port development (Figure 1). The first step consists of preliminary research, where all possible PPP alternatives are screened based on factors in association with the characteristics of the dry port project, including the legal framework, institutional framework, political perspectives, public budget conditions, and cultural factors to remove unlikely options. For example, a government with a tight budget and high deficit cannot afford traditional public procedures or contracting options, or political constraints might prevent the project from any privatisation in dry port ownership. This step results in a discrete set of PPP alternatives, which will serve as a base for the application of a multi-criteria analysis.

In the second step, we developed a set of criteria for PPP selection based on two main considerations: the benefits to stakeholders and risk management of the project. The benefits of the project are linked to the criteria that influence the objectives of relevant stakeholders. In line with the LAMBIT model (Macharis and Verbeke, 2002; Nguyen and Notteboom, 2016b), we group the stakeholders in homogenous categories with the same interests in the project. The public and community group cares for infrastructure development and the protection of social interest. Private investors and financiers look for an arrangement with a feasible financial viability. The users group including local shippers, transport companies, forwarders, and seaport actors, shares the interest of logistics desirability.

The criteria relevant to the benefits of these stakeholder groups as shown in Table 3 were selected based on 11 interviews with experts in terminal operations. The list of interviewees included Vietnamese government officials, PPP project managers, and scholars. We also performed a literature review of critical success factors of PPP, mainly relying on the studies of Aerts et al. (2014), Baizakov (2008), Becker and Patterson (2005), Emmanuel (2014), Li et al. (2005) and Zhang et al. (2012). The criteria were chosen in association with the properties of value relevance, clarity, measurability, completeness and non-redundancy (Diakoulaki and Grafakos, 2004).

The risks in the PPP contract are grouped at micro, macro and meso levels (Bing et al., 2005). Macro risks are exogenous uncertainties of a natural, national or industrial nature. They are not part of the scope of the PPP arrangement but can have significant effects on the project. Meso and micro risks are endogenous uncertainties, which can occur inside the project's boundary. The former are risks of implementing the PPP. For example, the project might not meet the expectations because of contracting parties' deficiency or overestimation. Micro risks are also internal factors, but are party-related instead of project-related. They include uncertainties linked to the stakeholder relationship within the project's limitation, including risks associated with the coordination between public and private actors and liabilities to third parties such as employees, customers or suppliers. The identification of the appropriate risk factors is based on studies of Bing et al. (2005), Karim (2011), The World Bank (2007), European Commission (2003), Athena Infonomics (2012) and are summarised in Table 4. 
Table 3 Criteria relevant to stakeholders' benefits in PPP selection

\begin{tabular}{|c|c|c|c|}
\hline Stakeholder & Criteria & Indicator & Explanation \\
\hline \multirow{3}{*}{$\begin{array}{l}\text { Public } \\
\text { authority and } \\
\text { community }\end{array}$} & $\begin{array}{l}\text { Access to } \\
\text { capital }\end{array}$ & $\begin{array}{l}\text { The proportion of private } \\
\text { investment in the project }\end{array}$ & $\begin{array}{l}\text { Partnership with private sector } \\
\text { will help the public sector to } \\
\text { solve funding problems }\end{array}$ \\
\hline & Direct revenue & $\begin{array}{l}\text { - Collection from users (user } \\
\text { fees) } \\
\text { - Concession fees }\end{array}$ & $\begin{array}{l}\text { In traditional public procurement, } \\
\text { the public party operates and } \\
\text { collects fees on their owns while } \\
\text { in a concession, the revenue } \\
\text { comes from concession fees }\end{array}$ \\
\hline & $\begin{array}{l}\text { Control over } \\
\text { assets }\end{array}$ & $\begin{array}{l}\text { Public ownership of the dry } \\
\text { port }\end{array}$ & $\begin{array}{l}\text { The government needs to } \\
\text { maintain control over the project } \\
\text { for political, environmental and } \\
\text { social reasons. }\end{array}$ \\
\hline \multirow{3}{*}{$\begin{array}{l}\text { Public } \\
\text { authority and } \\
\text { community }\end{array}$} & $\begin{array}{l}\text { Access to } \\
\text { technology } \\
\text { and expertise }\end{array}$ & $\begin{array}{l}\text { - Technology transferred } \\
\text { after the contract } \\
\text { - Trained human resource }\end{array}$ & \\
\hline & Market access & & $\begin{array}{l}\text { The private participant is } \\
\text { expected to reach higher cargo } \\
\text { demand for dry ports. }\end{array}$ \\
\hline & $\begin{array}{c}\text { Transaction } \\
\text { cost }\end{array}$ & $\begin{array}{l}\text { - Searching for the private } \\
\text { partner } \\
\text { - Negotiating the contract } \\
\text { - Policing and enforcing }\end{array}$ & $\begin{array}{c}\text { Transaction cost contains three } \\
\text { components as defined by } \\
\text { Dahlman (1979). This depends } \\
\text { on the complexity and experience } \\
\text { of the public sector in each PPP } \\
\text { arrangement }\end{array}$ \\
\hline \multirow{3}{*}{ Users } & $\begin{array}{l}\text { Quality of } \\
\text { service }\end{array}$ & $\begin{array}{l}\text { - Container storage } \\
\text { - Handling cargo } \\
\text { - Container repair }\end{array}$ & $\begin{array}{c}\text { Private participation is expected } \\
\text { to provide higher quality of } \\
\text { service to the user }\end{array}$ \\
\hline & & $\begin{array}{l}\text { - Custom clearance } \\
\text { - Value added service }\end{array}$ & \\
\hline & Service cost & & $\begin{array}{l}\text { Private participation should } \\
\text { provide the cost which reflect } \\
\text { better the service quality }\end{array}$ \\
\hline \multirow{4}{*}{$\begin{array}{l}\text { Private } \\
\text { investors and } \\
\text { financiers }\end{array}$} & $\begin{array}{l}\text { Market } \\
\text { elements }\end{array}$ & $\begin{array}{l}\text { - Market size } \\
\text { - Competition }\end{array}$ & $\begin{array}{c}\text { Bigger size and low competition } \\
\text { will attract more private } \\
\text { participation }\end{array}$ \\
\hline & $\begin{array}{l}\text { Connected } \\
\text { transport } \\
\text { infrastructure }\end{array}$ & $\begin{array}{l}\text { - Connection to seaports } \\
\text { - Connection to industrial } \\
\text { zones and markets }\end{array}$ & $\begin{array}{c}\text { Good transport connections are } \\
\text { essential for cargo flows through } \\
\text { dry ports }\end{array}$ \\
\hline & $\begin{array}{l}\text { Managerial } \\
\text { involvement }\end{array}$ & $\begin{array}{l}\text { Degree of private } \\
\text { management }\end{array}$ & $\begin{array}{l}\text { Arrangements with higher } \\
\text { private involvement will secure } \\
\text { more benefits to investors }\end{array}$ \\
\hline & $\begin{array}{l}\text { Investment } \\
\text { climate }\end{array}$ & $\begin{array}{l}\text { - Legal and institutional } \\
\text { framework } \\
\text { - Financial market } \\
\text { - Government support }\end{array}$ & $\begin{array}{l}\text { A better investment climate will } \\
\text { facilitate higher private } \\
\text { participation }\end{array}$ \\
\hline
\end{tabular}

Source: Own compilation based on various sources 
Table 4 Risk factors influencing PPP selection

\begin{tabular}{|c|c|c|c|}
\hline Risk group & Risk elements & Indicators & Explanation \\
\hline \multirow[t]{11}{*}{ Macro level } & Legal risk & & $\begin{array}{l}\text { A change in the current legal } \\
\text { framework relating to dry port } \\
\text { operation, such as tax, labour, } \\
\text { etc. }\end{array}$ \\
\hline & Financial risk & Inflation volatility & \\
\hline & & Interest rate volatility & \\
\hline & Market risk & Macro economic event & $\begin{array}{l}\text { A drop in cargo flows in a dry } \\
\text { port because of external } \\
\text { elements }\end{array}$ \\
\hline & & Competition & \\
\hline & Connection risk & & $\begin{array}{l}\text { Dysfunction of transport } \\
\text { connections to the dry port }\end{array}$ \\
\hline & Natural risk & Geotechnical risks & $\begin{array}{l}\text { High natural risks will } \\
\text { demotivate private participation }\end{array}$ \\
\hline & & Weather & \\
\hline & & Environment & \\
\hline & Force majeure & & Risks of war, strikes, disaster... \\
\hline & Political risk & & $\begin{array}{c}\text { Risks caused by unstable } \\
\text { government, expropriation or } \\
\text { nationalisation }\end{array}$ \\
\hline \multirow[t]{9}{*}{ Meso level } & Design risk & & \\
\hline & Approval delay & & \\
\hline & Land acquisition & & Delays in land acquisition \\
\hline & Construction & Cost overrun & $\begin{array}{l}\text { Defaults during construction } \\
\text { caused by the builder }\end{array}$ \\
\hline & & Time delay & \\
\hline & & Poor quality & \\
\hline & Operation risk & Cost overrun & $\begin{array}{l}\text { Risks related to the operation } \\
\text { and maintenance costs; } \\
\text { productivity is higher than } \\
\text { expected }\end{array}$ \\
\hline & & Low productivity & \\
\hline & & High maintenance & \\
\hline \multirow[t]{2}{*}{ Micro level } & Coordination risk & & $\begin{array}{l}\text { Conflict between contracting } \\
\text { parties caused by inexperience, } \\
\text { the complexity of the } \\
\text { arrangement, inappropriate } \\
\text { distribution of risk and rewards }\end{array}$ \\
\hline & Third party & & $\begin{array}{l}\text { Liability to the third party like } \\
\text { suppliers, employees... }\end{array}$ \\
\hline
\end{tabular}

Source: Own compilation based on various sources 
In Step 3, we define the importance of each criterion in the hierarchy and the input value for each alternative. The weights of the respective criteria are often collected through questionnaires given to groups of stakeholders using different methods, including pairwise comparison (Saaty, 2008), SWING (Von Winterfeldt and Edwards, 1986), direct point allocation and SMART (Edwards, 1977). AHP weighing is based on pairwise comparison. Direct point allocation is based on the allocation of points to criteria by the respondents. In the SWING method, the participants firstly choose the most important attribute and give it a score of 100 points. Then all other attributes are given a score of less than 100. The SMART technique starts with the least important attribute, giving it ten points, and then other attributes are weighed based on their relative importance in comparison with the former criterion. Pöyhönen and Hämäläinen (2001) concluded that there is no essential difference in results obtained from these methods so that the practitioner can choose a method following their personal preference. In the application part, we mainly apply the SWING method due to its simplicity and easy applicability. The inputs for each criterion related to each alternative are gathered from expert judgements using Likert scale, pairwise comparison, or quantitative figures from reports and calculations. These inputs were normalised with the highest input out of all alternatives receiving a value of 1 .

In Step 4, all inputs and weights are pooled in a multi-criteria analysis to rank PPP alternatives. The additive value function is applied to calculate the global rating of each alternative (Mustajoki et al., 2004):

$$
v(x)=\sum_{i=1}^{n} w_{i} v_{i}(x),
$$

where

$n \quad$ the number of criteria

$i \quad$ the criterion number

$w_{i} \quad$ the weight of criterion $i$

$v_{i}(x)$ the value of alternative $x$ in terms of criterion $i$, between 0 and 1 .

A sensitivity analysis is carried out to obtain a deeper understanding of the situation and to take into account suggestions for improvement.

\section{Application to a dry port case in Vietnam}

\subsection{Introduction to the case study}

Nguyen and Notteboom (2016a) pointed out that Vietnam is a good case study for dry port development, especially in developing countries due to a number of reasons. First, the country has a huge potential for maritime and inland transportation thanks to a long coastline and many industrial zones scattered along the country. The high logistics cost of over $20 \%$ of national GDP points to the existing inefficiency in inland transportation. The current dry port system contains many scattered and small-scale ICDs with limited logistics functions. 
Various PPP models have been applied in developing infrastructure in Vietnam for a long time. Statistics published by The World Bank indicate that from 1994 till 2014, 90 PPP projects in total were realised with a total investment of about 7.1 USD billion (Nhu, 2014). Most of these projects were carried out under BOT, BT, BTO and BOO schemes. About $70 \%$ of the PPP projects are in the transport sector, mostly related to roads and highways. In the port sector, Lach Huyen port is the first and only project up to now developed under a PPP contract. In the dry port sector, the government is still struggling to develop an appropriate model. This is hindering private sector participation and renders many projects unattractive to private investors.

The planning of the Vietnamese dry port development with a time horizon to 2030 is included in the Decision number 2223/QD-TTG of the Prime Minister. The government aims to develop 13 ICDs along the three main regions in the country with an expected total annual capacity of 6 million TEU in 2020 and 14 million in 2030. The shortage of public funds and the lack of experience in dry port development created strong incentives for PPP facilitation, which was realised through the issuance of a new regulation on PPP under decree No. 15 of 10th April 2015. The new regulation presents a single legal framework for PPP in Vietnam in line with international practice. It regulates the PPP fields, conditions and procedures in view of implementing PPP projects; the public investment and management mechanism in such projects; and, public support and responsibilities in managing PPP. Vietnam is also featuring in the APEC project "Promoting public-private partnership (PPP) to develop dry ports and logistics parks in order to enhance APEC's supply chain connectivity".

We apply the framework presented in the previous section in order to find the most appropriate PPP model for the Huong Canh ICD project (Vinh Phuc province). In line with the master plan of dry port development in Vietnam, Vinh Phuc Provincial People's Committee is planning a new ICD project of 100 ha inside the Huong Canh industrial zone, which will be the largest ICD in Northern Vietnam. Located along the Kunming (China) - Lao Cai - Hai Phong economic corridor, the ICD is connected to Hai Phong port by rail, as part of the Trans Asian Railway project running through Lao Cai - Hai Phong (Vietnam), and by road via the Trans Asian Highway AH14. The ICD is expected to serve the very promising market around Vinh Phuc and nearby provinces, including Tuyen Quang, Thai Nguyen, Ha Giang and Phu Tho. The project was authorised in 2009 but is still at the stage of searching private partners. A few investors, such as DeHan (Korea), have investigated the project's feasibility but they have not come up with a specific result. Therefore, we hope that this case study can assist the decision makers in selecting the most appropriate PPP model and to improve the attractiveness of the project to the private sector.

\subsection{Application}

As stated in Section 2.2, we limit the analysis to four dry port PPP models, including contracting out, inland terminal concession, field concession and privatised ownership. Figure 2 shows the structure of the PPP selection model. 
Figure 2 Model with weight allocation for PPP model selection in VINH PHUC ICD (see online version for colours)

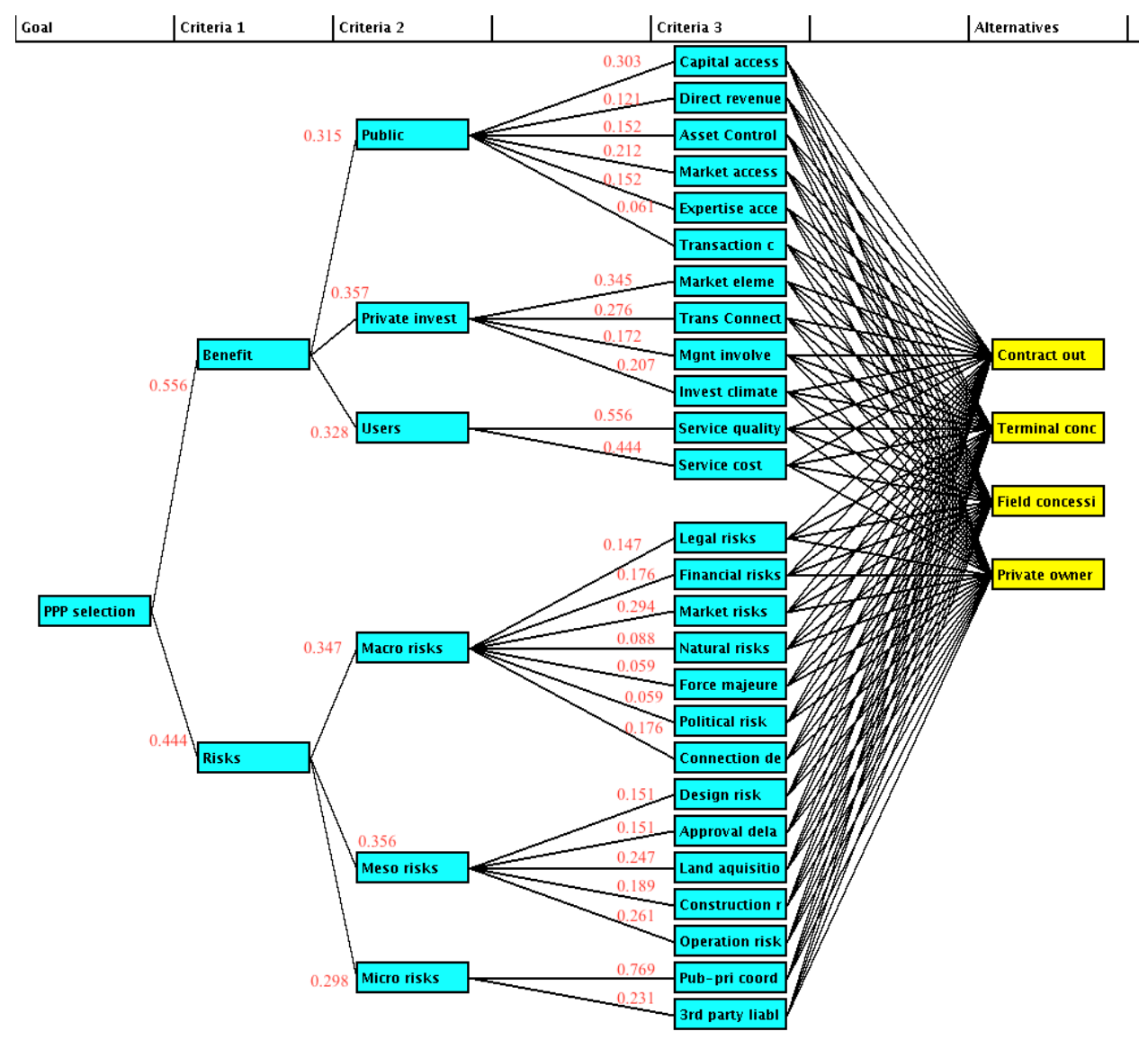

Source: Authors, created by Web-HIPRE software

The weights assigned for each element in Figure 2 were gathered from a survey carried in Vietnam. Despite efforts to have more respondents, given the Vietnamese context, we ended up with 17 participants in the survey, including researchers from Vietnam Maritime Universities and Transport Development and Strategy Institute of Ministry of Transportation, terminal operators from Lao Cai ICD, PPP Project Management of Ministry of Transport, logistics providers from VINALINE Logistics and Vinh Phuc project managers. All participants have more than five years of experience in a relevant field. Some $52.9 \%$ have more than 10 years of experience. In terms of education, $23.5 \%$ obtained a bachelor degree while the rest have a Master or higher degree. Out of 17 respondents, $58.8 \%$ is working as junior or senior manager. While the sample of respondents is quite limited, we believe the careful selection of participants provides an accurate reflection of stakeholders' perspectives in this Vietnamese case. In general, a small sample size increases the danger of bias, which can only be overcome by increasing the number of participants when the model is replicated in other contexts. 
The input for each criterion was obtained by consulting with the project managers of Vinh Phuc ICD using a Likert scale ranging from 1 to 5 . We calculated the overall ratings of each PPP model using Web-HIPRE software (Systems Analysis Laboratory, n.d.). The results are shown in Figures 3 and 4. The overall score is displayed on a scale from 0 to 1 .

Figure 3 Overall rankings split up between the criteria groups 'benefit' and 'risks' (see online version for colours)

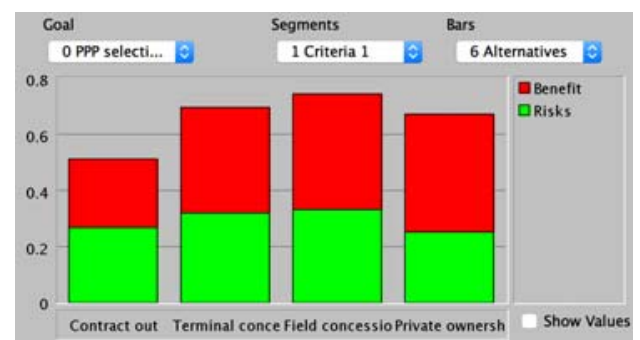

Source: Authors, created by Web-HIPRE software

Figure 4 (a) Rankings of PPP models in terms of 'benefits' with contribution of stakeholder groups (b) Rankings of PPP models in terms of 'risks' with contribution of risk groups (see online version for colours)

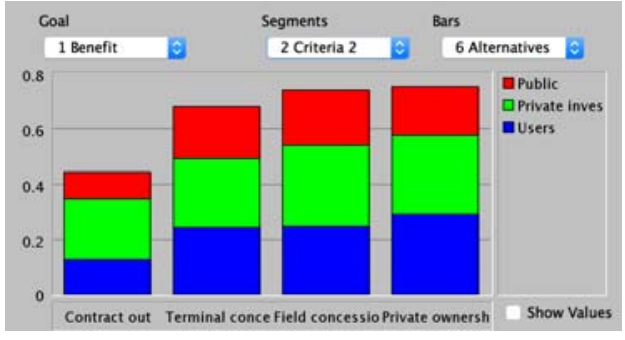

(a)

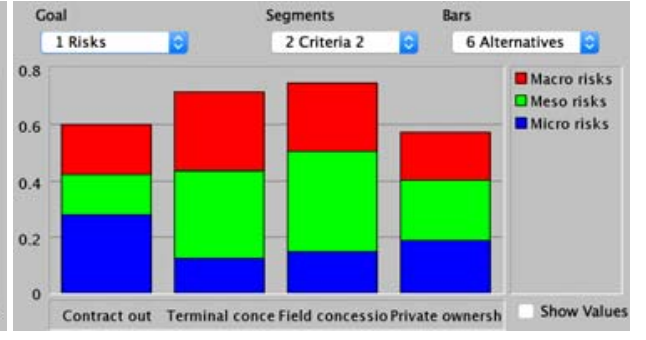

(b)

Source: Authors, created by Web-HIPRE software

The most appropriate PPP model for developing Vinh Phuc ICD is the field concession, thanks to the highest scores in terms of both the benefits to stakeholders and risk management. The second best alternative is the inland terminal concession, followed by private ownership and then contracting out. As shown in Figure 4(a), private ownership scores the best in terms of the 'Benefits' part. However, when it comes to risk management [Figure 4(b)], private ownership seems to be too risky at the macro and meso level. Field concessions offer the best risk management as the project related risks (meso level) are best managed with the participation of both public and private actors. The micro risk of the field concession option is still low because it is new to the Vietnamese government. The same applies to the terminal concession option. The worst option is the contracting out model since it does not help the government to gain access to private capital, which is an important criterion for Vietnam. The public procurement model is also very risky in the construction and operational phase, as well as there are high market uncertainties compared to the other options with high private involvement. 
Figure 5 Sensitivity analysis of global ranking by changing the weights of risk management (see online version for colours)

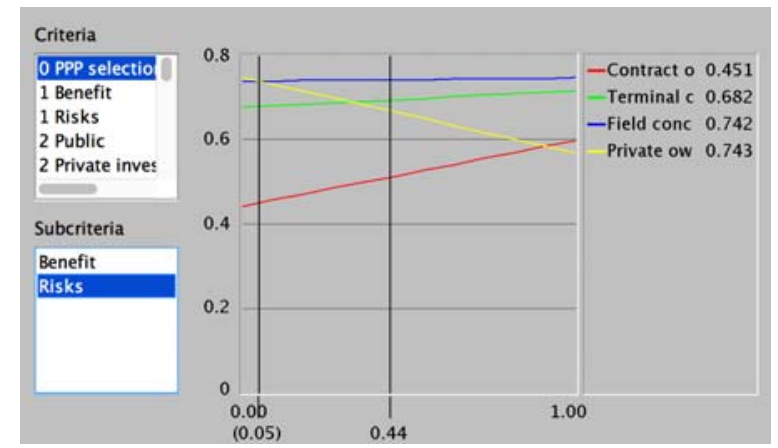

Source: Authors, created by Web-HIPRE software

Next, we developed a sensitivity analysis. In Figure 5, the vertical axis shows the overall ratings of the four alternatives (ranging from 0 to 1 ), marked by colour lines. The horizontal axis represents the relative weight of risk management (also from 0 to 1 ). The survey results point to an overall weight of risk-related criteria of 0.44 , making the field concession the preferred PPP model. The graph shows how the overall ranking changes when the weight of risks varies. When the weight of risks goes below 0.05 , the privatised ownership model becomes the best scoring option. In the other cases, the field concession is the best choice for developing Vinh Phuc ICD. We also tested how the global ranking changes if the weight of the elements in the second layer of criteria varies (Table 5). The cell content shows the weights' range of the criteria in the corresponding row when the alternative in the corresponding column scores the best. For example, when the weight of macro risks varies between 0 and 0.83 , the field concession option is the best choice. When the weight ranges from 0.83 to 1 , the inland terminal concession model becomes the preferred option. Similarly, if the weight of micro risks is lower than 0.67 , the field concession is the best option. Above this threshold weight the privatised ownership model ranks first.

Table 5 Sensitivity analysis in terms of sub criteria of benefits and risks

\begin{tabular}{lcccccc}
\hline & Criteria & $\begin{array}{c}\text { Current } \\
\text { weighs }\end{array}$ & $\begin{array}{c}\text { Contracting } \\
\text { out }\end{array}$ & $\begin{array}{c}\text { Inland } \\
\text { terminal } \\
\text { concession }\end{array}$ & $\begin{array}{c}\text { Field } \\
\text { concession }\end{array}$ & $\begin{array}{c}\text { Privatised } \\
\text { ownership }\end{array}$ \\
\hline $\begin{array}{l}\text { Benefit } \\
(0.556)\end{array}$ & $\begin{array}{c}\text { Public and } \\
\text { community } \\
\text { Private }\end{array}$ & 0.315 & $\begin{array}{c}\text { N/A } \\
\text { (not available) }\end{array}$ & N/A & N/A & N/A \\
& $\begin{array}{c}\text { investors } \\
\text { and } \\
\text { financiers }\end{array}$ & & N/A & N/A & N/A & N/A \\
& Users & 0.328 & N/A & N/A & N/A & N/A \\
& $\begin{array}{c}\text { Macro risks } \\
\text { Risk }\end{array}$ & 0.347 & N/A & $0.83-1$ & $0-0.83$ & N/A \\
$(0.444)$ & Meso risks & 0.356 & N/A & N/A & N/A & N/A \\
& Micro risks & 0.298 & N/A & N/A & $0-0.67$ & $0.67-1$ \\
\hline
\end{tabular}

Source: Authors 
We also carried out a sensitivity analysis to the criteria in the most detailed layer of the criteria set. The field concession model still dominates in most cases when the weights of the criteria are changed. Only in a few cases (such as asset control and direct revenue) do we observe that significant changes in the weights of these criteria lead to the inland terminal concession option as the preferred model.

\section{Conclusions}

In this paper, we presented a conceptual framework that can assist in selecting the best PPP model for dry port development. We focused on four categories of PPP models for dry port development: the contracting out model, inland terminal concession, field concession and the privatised ownership model. The framework for benchmarking PPP models is based on a multi-criteria analysis with a risk-benefit approach. The group of 'benefit' criteria is linked to the benefits for the three main stakeholder groups, including the governments at different levels and the community, private investors and financiers, and dry port users. In terms of risks, the proposed framework covers the risk management of each alternative at the macro, meso and micro levels.

We applied the framework to find the best PPP model for the Vinh Phuc ICD in Vietnam. The results show that the field concession option is the most appropriate model for developing Vinh Phuc ICD. We also carried out a sensitivity analysis to see how the overall ranking of the PPP models changes as a function of the relative weights of the criteria.

In order to apply the framework in other contexts, the user needs to customise the weight allocation in the third layer of criteria in this model by consulting with local experts. This would help to better describe the applied situation. This step is also the biggest potential bias of the framework as it relies on subjective judgements within a specific regional context of dry port development. In order to reduce bias, the weight allocation should reach a high consensus of all stakeholders and preferably a large sample size of respondents. For example, the survey among all stakeholder representatives might be run in multiple rounds in order to reach a certain level of consensus and convergence on the weights and scores.

\section{References}

Aerts, G., Grage, T., Dooms, M. and Haezendonck, E. (2014) 'Public-private partnerships for the provision of port infrastructure: an explorative multi-actor perspective on critical success factors', The Asian Journal of Shipping and Logistics, Vol. 30, No. 3, pp.273-298.

APEC (2015) Public-Private Partnerships in Thailand: A Case Study of Lat Krabang Inland Container Depot.

Athena Infonomics (2012) Public Private Partnerships: Lessons from Experiences [online] https://www.gov.uk/government/uploads/system/uploads/attachment_data/file/186989/ Report-PPPLessonsFromExperiences270812.pdf [accessed 28 January 2016].

Baizakov, S. (2008) Guidebook on Promoting Good Governance in Public-Private Partnership, United Nations, Geneva.

Becker, F. and Patterson, V. (2005) 'Public-private partnerships: Balancing financial returns, risks, and roles of the partners', Public Performance and Management Review, Vol. 29, No. 2, pp.125-144. 
Beresford, A., Pettit, S., Xu, Q. and Williams, S. (2012) 'A study of dry port development in China', Maritime Economics and Logistics, Vol. 14, No. 1, pp.73-98.

Bing, L., Akintoye, A., Edwards, P.J. and Hardcastle, C. (2005) 'The allocation of risk in PPP/PFI construction projects in the UK', International Journal of Project Management, Vol. 23, No. 1, pp.25-35.

Checherita, C. and Gifford, J. (2007) 'Risk sharing in public-private partnerships: general considerations and an evaluation of the US Practice in road transportation', Paper presented at the Transportation Research Forum.

Chhotray, V. and Stoker, G. (2008) 'Governance theory and practice: a cross-disciplinary approach', Public Administration, Vol. 87, No. 4, pp.982-983.

Cullinane, K., Bergqvist, R. and Wilmsmeier, G. (2012) 'The dry port concept - theory and practice', Maritime Economics and Logistics, Vol. 14, No. 1, pp.1-13.

Dahlman, C.J. (1979) 'The problem of externality', The Journal of Law and Economics, Vol. 22, No. 1, pp.141-162.

Diakoulaki, D. and Grafakos, S. (2004) Multicriteria Analysis, Working paper, European Commission Externalities of Energy Research Network, National Technical University Athens, Greece.

Edwards, W. (1977) 'How to use multiattribute utility measurement for social decision making', IEEE Transactions on Systems, Man and Cybernetics, Vol. 7, No. 5, pp.326-340.

Emmanuel, O. (2014) 'Critical success factors (Csf) determining the implementation of public-private partnership projects', Covenant Journal of Research in the Built Environment (CJRBE), Vol. 1, No. 2, pp.41-66.

European Commission (2003) Guidelines for Successful Public-Private Partnerships, DG Regional Policy [online] http://ec.europa.eu/regional_policy/sources/docgener/guides/ppp_en.pdf (accessed 28 January 2016).

Farrell, S. (2011) 'Observations on PPP models in the ports sector', Paper presented at the COST Symposium Public Private Partnerships in Transport: Trends and Theory-Research Roadmap, Lisbon.

Farrell, S. and Vanelslander, T. (2015) 'Comparison of public-private partnerships in airports and seaports in low-and middle-income countries', Transport Reviews, Vol. 35, No. 3, pp.329-351.

Freeman, R.E. (2010) Strategic Management: A Stakeholder Approach, Cambridge University Press, New York.

Hammami, M., Ruhashyankiko, J-F. and Yehoue, E.B. (2006) Determinants of Public-Private Partnerships in Infrastructure, IMF working paper, 06/99, International Monetary Fund, Washington.

Hanaoka, S. and Regmi, M.B. (2011) 'Promoting intermodal freight transport through the development of dry ports in Asia: an environmental perspective', IATSS Research, Vol. 35, No. 1, pp.16-23.

Haralambides, H. and Gujar, G. (2011) 'The Indian dry ports sector, pricing policies and opportunities for public-private partnerships', Research in Transportation Economics, Vol. 33, No. 1, pp.51-58.

IFC (2015) Public-Private Partnership Stories Niger: Dry Port [online] http://www.ifc.org/wps/wcm/connect/7594dd0047b328349dcdfd299ede9589/PPP+Stories++ Niger+Dry+Port+19+March+2015.pdf?MOD=AJPERES (accessed 9 November 2015).

Karim, N.A.A. (2011) 'Risk allocation in public private partnership (PPP) project: a review on risk factors', International Journal of Sustainable Construction Engineering and Technology, Vol. 2, No. 2, pp.8-16.

Li, B., Akintoye, A., Edwards, P.J. and Hardcastle, C. (2005) 'Critical success factors for PPP/PFI projects in the UK construction industry', Construction Management and Economics, Vol. 23, No. 5, pp.459-471. 
Macharis, C. and Verbeke, A. (2002) 'Location analysis for Belgian intermodal terminals', Current Issues in Port Logistics and Intermodality, pp.99-123, Garant, Antwerp/Apeldoorn.

Monios, J. (2015) 'Identifying governance relationships between intermodal terminals and logistics platforms', Transport Reviews, Vol. 35, No. 6, pp.767-791.

Mustajoki, J., Hämäläinen, R.P. and Marttunen, M. (2004) 'Participatory multicriteria decision analysis with Web-HIPRE: a case of lake regulation policy', Environmental Modelling and Software, Vol. 19, No. 6, pp.537-547.

Nguyen, L.C. and Notteboom, T. (2016a) 'Dry ports as extensions of maritime deep-sea ports: a case study of Vietnam', Journal of International Logistics and Trade, Vol. 14, No. 1, pp.65-88.

Nguyen, L.C. and Notteboom, T. (2016b) 'A multi-criteria approach to dry port location in developing economies with application to Vietnam', The Asian Journal of Shipping and Logistics, Vol. 32, No. 1, pp.23-32.

Nhu, B.T. (2014) 'Hợp tác công tư trong đầu tư cơ sở hạ tầng tại Việt Nam (Pulic private partnership in developing infrastructure in Vietnam)', Macro Finance, Vol. 3, No. 128, pp.7-9.

Notteboom, T. and Rodrigue, J.P. (2005) 'Port regionalization: towards a new phase in port development', Maritime Policy and Management, Vol. 32, No. 3, pp.297-313.

Notteboom, T. and Rodrigue, J-P. (2009) 'Inland terminals within North American and European supply chains', Transport and Communications Bulletin for Asia and the Pacific, Vol. 78, No. 1, pp.1-39.

Notteboom, T., Parola, F., Satta, G. and Risitano, M. (2017) 'A taxonomy of logistics centres: overcoming conceptual ambiguity', Transport Reviews, Vol. 37, No. 3, pp.276-299.

Pöyhönen, M. and Hämäläinen, R.P. (2001) 'On the convergence of multiattribute weighting methods', European Journal of Operational Research, Vol. 129, No. 3, pp.569-585.

PPIAF (2009) Toolkit for Public-Private Partnership in Roads and Highways [online] https://www.ppiaf.org/sites/ppiaf.org/files/documents/toolkits/highwaystoolkit/6/pdfversion/5-36.pdf (accessed 23 November 2015).

PPIAF (2012) PPP Basics and Principles of a PPP Framework [online] http://www.ppiaf.org/sites/ ppiaf.org/files/documents/Note-One-PPP-Basics-and-Principles-of-a-PPP-Framework.pdf (accessed 2 March 2016).

PPPIRC (2014) What are Public Private Partnerships? [online] http://ppp.worldbank.org/ public-private-partnership/overview/what-are-public-private-partnerships (accessed 10 January 2016).

Roso, V., Woxenius, J. and Lumsden, K. (2009) 'The dry port concept: connecting container seaports with the hinterland', Journal of Transport Geography, Vol. 17, No. 5, pp.338-345.

Saaty, T.L. (2008) 'Decision making with the analytic hierarchy process', International journal of Services Sciences, Vol. 1, No. 1, pp.83-98.

Shukla, N., Panchal, R. and Shah, N. (2014) 'Built-own-lease-transfer (BOLT): a public private partnership model that bridges gap of infrastructure in urban areas', International Journal of Civil Engineering Research, Vol. 5, No. 2, pp.135-144.

Systems Analysis Laboratory (n.d.) User guide for Web-HIPRE 2.0 with RODOS [online] https://resy5.iket.kit.edu/RODOS/Documents/Public/HandbookV6f/Volume1/Web-HIPRE_ user_guide.pdf (accessed 2 March 2016).

The World Bank (2003) A Railway Concessioning Toolkit, Press release [online] http://www.ssatp.org/sites/ssatp/files/publications/SSATP-WorkingPapers/SSATPWP74.pdf (accessed 10 January 2016).

The World Bank (2007) Port Reform Toolkit.

The World Bank (2015) PPP Arrangements/Types of Public-Private Partnership Agreements [online] http://ppp.worldbank.org/public-private-partnership/agreements (accessed 10 January 2015). 
Turpin, F-M. (2013) 'PPP in ports, landlord port model', Tbilisi, Georgia [online] http://www.traceca-org.org/uploads/media/04_Module_C_PPP_Francois_Marc_Turpin_ new.pdf (accessed 10 January 2015).

UNCTAD (1982) Multimodal Transport and Containerisation, TD/B/C.4/238/Supplement 1, Part 5: Ports and Container Depots, Geneva.

Van Ham, H. and Koppenjan, J. (2001) 'Building public-private partnerships: assessing and managing risks in port development', Public Management Review, Vol. 3, No. 4, pp.593-616.

Von Winterfeldt, D. and Edwards, W. (1986) Decision Analysis and Behavioral Research, Cambridge University Press, New York.

Yescombe, E.R. (2011) Public-Private Partnerships: Principles of Policy and Finance, Butterworth-Heinemann, Oxford.

Zhang, X., Cheung, E., Chan, A.P., Lam, P.T., Chan, D.W. and Ke, Y. (2012) 'A comparative study of critical success factors for public private partnerships (PPP) between Mainland China and the Hong Kong Special Administrative Region', Facilities, Vol. 30, Nos. 13/14, pp.647-666. 